\title{
The base and the noble
}

\section{Walter Gratzer}

The Periodic Table. By Primo Levi. Translated by Raymond Rosenthal Michael Joseph/Schocken: 1985. Pp.233. £9.95, \$16.95.

THE language of chemistry, alone among the sciences, is shot through with antique imagery, compounded of astrology, folklore and the occult; it is the language of the alchemists and iatrochemists and of the atavistic quest for transmutation of base into noble. Each chapter in The Periodic Table bears the name of an element, serving sometimès to evoke its ancient symbolism and sometimes to recall an episode in the author's life. For Primo Levi was a journeyman chemist, a professional with a robust pride in his calling. Chief among the several fictional interludes in his book is a powerful fable about a travelling lead smelter, who explores the ancient Mediterranean in search of deposits, proud of his arcane craft and careless of the early death from plumbism that he knows will claim him, as it did his forbears.

Levi is one of a line of Jewish-Italian writers - Svevo, Moravia, Bassani, Carlo Levi - who have chronicled aspects of Italian society in the first half of our century, and in his first chapter, "Argon" the obdurate, the noble gas that enters into no combinations with other elements - he describes his early life in a community, presumably now vanished, and new to me, that of the Piedmontese Jews. His forbears came from Provence by way of Spain in the fifteenth century, and many of the names reflect their origins. The name of the little town of Lunel, near Nîmes, was rendered into Hebrew as yareakh, the Moon, whence Jarach, a noted Jewish-Piedmontese surname. Levi grew up speaking a patois of Hebrew with Piedmontese inflexions and grammar: "Davidin, bat la cana, c'as sento nen le rukhod" his Aunt Regina would say to Uncle David, as they sat in a cafe in Saluzzo - "David, bang your stick, so that they don't hear your winds".

Levi became absorbed in chemistry as a schoolboy and went to study at Turin University. About this time Mussolini promulgated the notorious Manifesto della Raz$z a$, which debarred members of "nonAryan races" from professional careers. Two distinguished Jewish-Italian scientists, both from Turin, Salvador Luria and Rita Levi-Montalcini, have written about the impact that this had on their lives. (Both came under the influence at the University of yet another Levi, Giuseppe, a respected histologist and a heroic opponent of the Fascists. Luria got away, to be washed up eventually on the other side of the Atlantic, while Levi-Montalcini went into hiding and set up a laboratory in her kitchen, with Giuseppe Levi as her assistant, and there laid the foundation of her later work on embryology.) Primo Levi also found refuge in his work, having been offered a modest position as analyst in a mine outside Turin, where he embarked on a project to extract nickel (the demon) from the exhausted detritus of the plant. At a time when, as Levi says, "only a

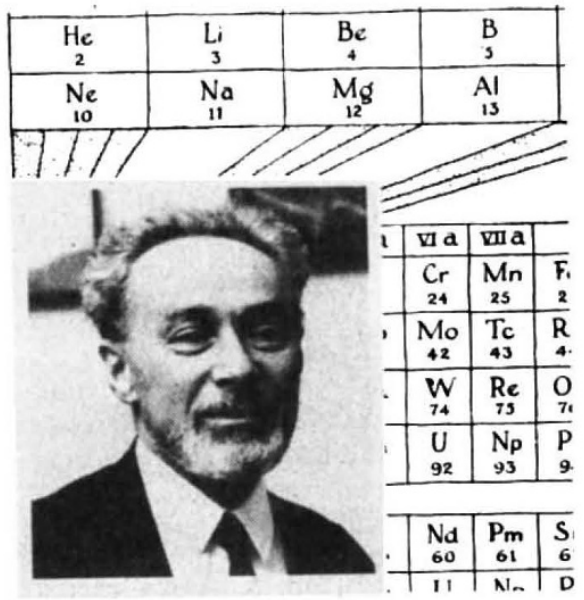

voluntarily deaf and blind man could have [had] any doubts about the fate reserved for the Jews in a German Europe", he immersed himself in his chemistry and took pleasure in the gallery of extraordinary characters around him. He achieved a Pyrrhic but intensely satisfying triumph in the laboratory and got the nickel out - an abundant pink precipitate with dimethylglyoxime. An aspiration is indeed, as Robert Louis Stevenson observed, a joy forever, a possession as solid as a landed estate.

Chemistry did more for Levi a year later, for in 1942 he joined a Partisan group - "the most disarmed partisans in the Piedmont, and probably the most unprepared" - and was forthwith captured. In Auschwitz, an experience of which he has written without rancour in another book, he was selected to work in the Bunarubber factory, and so survived. With a friend (who did not), he kept starvation precariously at bay by selling to a clandestine cottage industry in the camp flints for cigarette lighters, chipped from rods of what he had managed to identify as ironcerium alloy.

In the bleak years that followed the war Levi plied his trade, first in a paint factory ("Chromium"), where, by a tour de force of analytical chemistry and detective work in the company records, he found both the reason and the cure for the "livering" of batches of paint, that is to say their trans- formation into a solid mass with the texture and aspect of offal. He set up with a friend a home analytical laboratory and took on contracts for disreputable entrepreneurs. Worst among these was a manufacturer of cosmetics, who made cheap lipstick with a soluble base, that ran. For a better, kissproof formula, alloxan was required and Levi set about synthesizing it from uric acid, to be extracted from chicken droppings; these he and his remarkably game bride collected from poultry farms and separated from earth, pebbles, feathers and lice. The preparation did not work and the excrement remained untransmuted and malodorous; so much for nitrogen.

The business failed resoundingly, and in "Vanadium" Levi finds himself back in a factory, superintending the manufacture of varnishes. Here a remarkable experience befalls him: some shipments of resin from IG-Farben are found to give rise to a product that refuses to dry. The correspondence that ensues focuses eventually on the use of an organo-vanadium catalyst, and is conducted from the German side by a certain Dr Müller; could it be, as certain quirks of spelling and style in the letters suggest, the same Dr Müller for whom Levi worked at Auschwitz? It was, and for Levi this seemed to bring the chance, long dreamed of, to confront, if only at a distance, one of Them - not, says Levi, for revenge but to exorcize a monstrous anomaly, "to re-establish the right proportions". Dr Müller, on receiving Levi's letter, together with a copy of his book about Auschwitz, displays feelings of confusion and regret, not amounting altogether to remorse, and strikes a discordant and painfully sentimental tone in his long reply. According to Oscar Wilde, a sentimentalist is one who desires the luxury of an emotion without wanting to pay for it. Such a one is Dr Müller. When he writes again and proposes a visit to Turin, Levi is dismayed. Dr Müller insists, but the story has a poignant ending, for, before the encounter can be consummated, Levi receives the announcement of the unexpected demise of Dr Lothar Müller in the sixtieth year of his life.

Horace Walpole said that life is a comedy to those who think and a tragedy to those who feel. Primo Levi does both, but he maintains, in the face of the turbulent events that he describes, a quizzical detachment. It is partly this quality that makes The Periodic Table such a transfixing book, and one that eludes categorization. It is learned, funny and elegaic, and with "Carbon" - a fancy that pursues the journey of a carbon atom from its place in a limestone lattice into the brain of the writer - it evanesces, leaving the smile of the alchemist to linger in the memory.

Walter Gratzer is in the Medical Research Council Cell Biophysics Unit, Kings College London (KQC), 26-29 Drury Lane, London WC2B SRL, UK 